\title{
Neuropatía sensitiva trigeminal secundaria a granuloma de colesterol de la punta del peñasco del temporal
}

\section{Trigeminal neuralgia secondary to cholesterol granuloma of the petrous bone apex}

\author{
M.A. Pons García', C. Moreno García
}

Resumen: La neuropatía aislada de la rama sensitiva del trigémino es una entidad poco habitual. Los pacientes suelen referir hipoestesia y /o disestesia generalmente a nivel de la segunda y tercera rama del trigémino, mientras que la neuralgia es muy infrecuente. ${ }^{1}$ Su asociación con enfermedades sistémicas del tejido conectivo es bien conocida. ${ }^{2}$ Se ha descrito asociada a distintas lesiones del SNC sobre todo tumores de fosa posterior o base de cráneo, así como neoplasias mandibulares.3,4 Presentamos una paciente con hipoestesia en el territorio V2-V3 asociada a dolor hemifacial paroxístico secundario a una lesión del peñasco del temporal.

Palabras clave: Neuropatía trigeminal; Hipoestesia orofacial; Peñasco del temporal.

Recibido: 23.11.2008

Aceptado: 24.09.2009
Abstract: Trigeminal Neuralgia is an uncommon entity. The patients report hypoesthesia and/or dysesthesia of the second and third ramus of trigeminal nerve, while neuralgia is very rare. ${ }^{1}$ Its association with systemic diseases of connective tissue is well know. ${ }^{2}$ It has been described as being associated with different lesions of the central nervous system, especially with the posterior cavity or cranial base tumors, as well as jaw neoplasias.3,4 We presented a patient with hypoesthesia V2-V3 and hemi facial paroxysmal pain secondary to lesion of petrous apex of temporal bone.

Key words: Trigeminal neuropathy; Orofacial hypoalgesia; Petrous apex of temporal bone.

1 Neuróloga. Servicio de Neurología.

2 Cirujano Oral y Maxilofacial.

Servicio de Cirugía Oral y Maxilofacial.

Hospital Infanta Cristina. Badajoz. España

\section{Correspondencia:}

Carlos Moreno García

Servicio Cirugía y Maxilofacial

Hospital Infanta Cristina. Crta. de Portugal, s/n. Badajoz

Email: carlosmorenogar@gmail.com 


\section{Introducción}

La neuropatía sensitiva trigeminal cursa con una sensación de hipoestesia y/o disestesia de apariencia brusca o gradual, continua u ocasional, limitada generalmente a la segunda y tercera rama del nervio trigémino, de duración variable y sin déficit motor asociado. Es una patología infrecuente, aunque bien conocida, por los expertos en el tema y que en los últimos años ha sido objeto de interés. Se ha descrito asociada a conectivopatías, infecciones del SNC, dilataciones vasculares y a distintos tipos de tumores sobre todo a meningiomas. La localización más frecuente de estas lesiones es la fosa posterior. ${ }^{5,6}$ Según la literatura revisada, es excepcional su asociación con tumores grasos del ápex del peñasco del temporal, de ahí el interés de presentarles este caso.

\section{Caso clínico}

Mujer de 60 años con antecedentes de dislipemia y cefalea de tensión crónica, que acude a consulta por presentar en los dos últimos meses, episodios de dolor hemifacial izquierdo de segundos de duración, lancinante, a nivel de la segunda y tercera rama del nervio trigémino.

Los episodios se desencadenan fundamentalmente al roce de la cara, al reírse o masticar, y tras ellos permanece una sensación de hipoestesia y tumefacción en esta localización. Puede presentar hasta tres episodios diarios.

No refiere cefalea acompañante, ojo rojo, lagrimeo ni rinorrea. No se acompaña de movimientos anormales en esa hemicara. Niega disfagia u otros síntomas.

A la exploración física la paciente esta vigil, orientada, colaboradora, existe isocoria y normorreacción pupilar, los movimientos oculares son normales así como el fondo de ojo. La exploración de los pares craneales es normal a excepción de una hipoestesia en la $2^{\underline{a}}$ y $3^{\underline{a}}$ rama del $V$ p.c. izquierdo. No presenta disfagia o alteración del lenguaje. No existe déficit motor o sensitivo asociado a otros niveles. Los reflejos osteotendinosos están presentes y simétricos. El resto de la exploración neurológica y general es normal.

Se solicita analítica destacando una hipercolesterolemia e hipertrigliceridemia.

En la RMN cerebral (Figs. 1 y 2) potenciada en T1, T2 y FLAIR con secuencias de supresión grasa, se objetiva una formación alargada a nivel de ápex petroso izquierdo de $28 \mathrm{~mm}$ de diámetro mayor, que contacta con la pared del seno esfenoidal y celdillas etmoidales posteriores así como con la carótida intrapetrosa sin provocar alteración en el flujo de esta, que no realza tras la administración de contraste, siendo compatible con un granuloma de colesterol de la punta del peñasco como primera posibilidad. Además se detecta silla turca vacía como hallazgo casual.

Tras valorar a la paciente se instaura tratamiento sintomático con carbamazepina a dosis de $400 \mathrm{mg} /$ día, con buena respuesta. A las 48 horas del inicio del tratamiento la paciente se encuentra asintomática, desapareciendo no solo el dolor si no también la hipoestesia, optándose de momento por tratamiento conservador.

\section{Introduction}

Trigeminal neuralgia involves a hypoesthesia and/or dysesthesia sensation and it appears either suddenly or gradually. It is generally limited to the second or third branch of the trigeminal nerve, lasts for a variable amount of time and does not have an associated motor deficit. It is an uncommon pathology, although it is well known by experts in the field and in the last few years it has been a topic of interest. It has been described as being associated with connective tissue disease, central nervous system infections, vascular enlargement and different types of tumors, especially meningiomas. The most common site for these lesions is the posterior cavity. ${ }^{5,6}$ According to the literature reviewed, its association with fatty apex tumors of the petrous bone is exceptional, that is what sparked our interest and made us decide to present this case.

\section{Clinical Case}

60 year-old female with a medical history of dyslipidemia and chronic tension cephalea. She goes to the doctor because of pain episodes in the left side of the face that last a few seconds and have been going on for the last 2 months. The pain is shooting/stabbing and takes place in the second and third branch of the trigeminal nerve.

The episodes are provoked by the friction in the face when laughing or chewing and afterwards there is a sensation of hypoesthesia and swelling in this site. It can happen up to three times a day. The patient does not report cephalea, red eye, weeping or runny nose. There are no abnormal movements in this side of the face, dysphagia or other symptoms.

The physical exam reports the patient as vigil, oriented and cooperative. There is isochoric and pupil normorreaccion, eye movement is normal and so is the back of the eye. Examination of the cranial pair is normal except that a hypoesthesia is in the 2nd and 3rd left branch. There is no dysphagia or changes in speech. There is no motor deficit or associated sensitivity in other areas. Reflexes are present and symmetric. The rest of the neurological and general exam is normal. They ask for analysis to rule out hypercholesterolemia and hypertriglyceridmia. The brain MRI increased the power in T1, T2 and FLAIR with fat suppressing sequences that caused the lengthening the diameter of the left petrous apex $28 \mathrm{~mm}$. It touches the posterior sphenoid sinus and small ethmoidal cells like the intrapetrous carotid. This takes place without changing its flow that doesn't enhance after administering the contrast; it is compatible with cholesterol granuloma of the point of the petrous bone. We also casually discovered an empty sella turcica.

After evaluating the patient we establish $400 \mathrm{mg} /$ day of carbamazepine is appropriate to treat the symptoms. 48 hours after starting treatment the patient has no symptoms, 

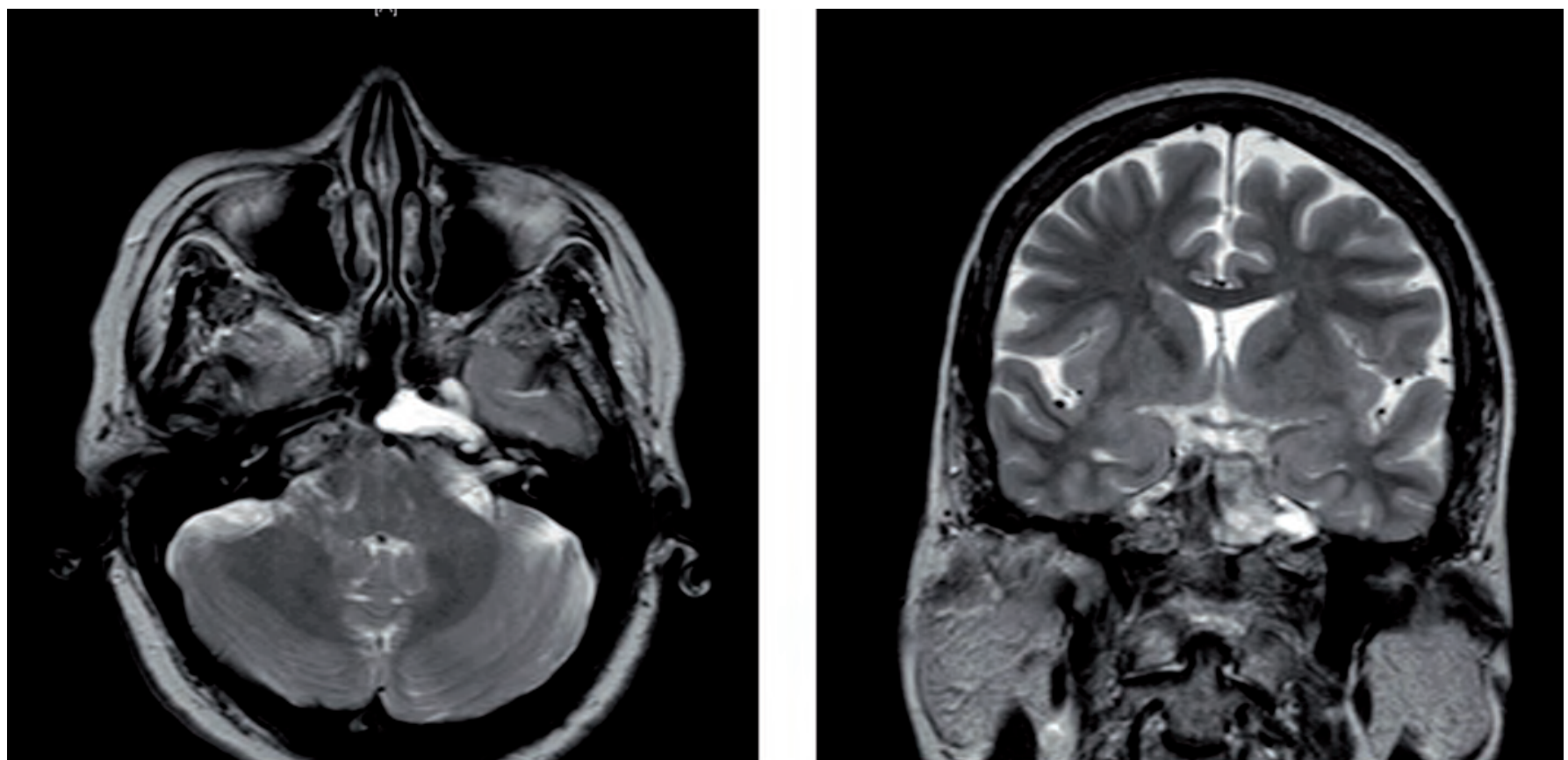

Figuras 1 y 2. RMN cerebral: se objetiva formación alargada a nivel de ápex petroso izquierdo que contacta con la pared del seno esfenoidal y celdillas etmoidales posteriores así como con la carótida intrapetrosa.

Figures 1 and 2. Cerebral MRI: formation along the left petrous apex that touches the wall of the sphenoid sinus and the small posterior ethimoid cells like the intrapetrous carotid.

\section{Discusión}

Las neuropatías del trigémino de origen tumoral suponen un bajo porcentaje de las neuropatías trigeminales. Se manifiestan como un adormecimiento cutáneo-mucoso en la región inervada por el trigémino, siendo más frecuente la afectación de V2 y V3, sobre todo de la rama maxilar. Su importancia radica en que pueden ser la primera manifestación clínica de un tumor (benigno o maligno) o de una recidiva en pacientes con neoplasias previas. De estos, los meningiomas de fosa posterior, son el tipo y localización más frecuente. ${ }^{7}$

Sin embargo, la asociación más descrita se ha realizado con enfermedades sistémicas particularmente con la esclerosis sistémica, enfermedad mixta del tejido conjuntivo y síndrome de Sjögren, la diferencia es que en este caso no suele ser una manifestación precoz de la enfermedad. Se han descrito también neuropatías sensitivas trigeminales en relación a infecciones (herpes zoster, neurosífilis, tuberculosis), aracnoiditis y traumatismos. ${ }^{8,9}$

El nervio trigémino a lo largo de su trayecto puede lesionarse a distintos niveles desde el tronco encéfalo, raíces preganglionares, ganglio de Gasser hasta la porción periférica del nervio. El ganglio de Gasser está situado en un receso de la duramadre llamado cavum de Meckel, localizado en la parte anterosuperior del ápex del peñasco del hueso temporal.

La clínica más frecuente es la hipoestesia y/o disestesia y en menor grado la neuralgia. La mayoría de los pacientes describen las disestesias como de intensidad moderada, un $60 \%$ refieren dolor neuropático ocasional y el $80 \%$ presenta hipoestesia a la exploración neurológica. ${ }^{8}$ La neuropatía mentoniana maligna está carac- both the pain and hypoesthesia have disappeared, opting for conservative treatment at the moment.

\section{Discussion}

Trigeminal neuralgias that originate from tumors make up a small percentage of trigeminal neuralgias. They start as cutaneous-mucosa drowsiness in the region of the trigeminal, mainly affecting the V2 and V3, especially in the maxilla branch. Its importance is established by its ability to be the first clinical manifestation (benign or malignant) or relapse in patients with previous neoplasias. Of these, meningioma of the posterior cavity is the most frequent type and location.

However, the most described association was of systematic illnesses, particularly of systematic sclerosis, mixed conjunctive tissue disease and Sjorgen syndrome. The difference is that in this case there aren't usually manifestations prior to the disease. Sensitive neuropathy trigemina has been described in relation to infections (herpes zoster, neurosyphilis, and tuberculosis) arachnoiditis and traumas. ${ }^{8,9}$

The trigeminal nerve can be damaged in different areas from the encephalon trunk, preganglionated roots and Gasser ganglion to the portion of the peripheral nerve. The Gasser ganglion is located in the upper anterior portion of the apex of the temporal bone.

The most frequent clinic is hypoesthesia and/or dysesthesia and the least frequent is neuralgia. The majority of 
terizada por la anestesia espontánea de la región inervada por el nervio mentoniano y el déficit sensitivo abarca piel mentón y piel y mucosa del labio inferior.

Los tumores de contenido graso, entre los que se encuentra el granuloma de colesterol, son muy infrecuentes, siendo el 0,1\% de todos los tumores intracraneales y generalmente asintomáticos. Se localizan sobre todo a nivel mediosagital cerca del cuerpo calloso y ángulo pontocerebeloso. Con menos frecuencia se sitúan en mesencéfalo dorsal, vermis cerebeloso, médula y base de cráneo. ${ }^{10-12}$

Ante una neuropatía del trigémino es por tanto imprescindible la realización de un estudio radiológico completo para descartar lesiones a nivel del cerebral, de tronco, preganglionares o del ganglio de Gasser y seno cavernoso así como de la zona extracraneal en todo el trayecto de las tres ramas del V par craneal. ${ }^{12}$

Las técnicas de neuroimagen nos ayudan a realizar el diagnóstico diferencial de las distintas lesiones que afectan a la punta del peñasco del temporal. Así, el granuloma de colesterol se presenta como un proceso expansivo, hipointenso en el TAC donde además se objetiva como erosiona el hueso adyacente e hiperintenso en la RMN potenciada en T1, T2, FLAIR y densidad protónica, anulándose su señal en secuencias de supresión grasa. ${ }^{12,13}$ La cavidad central es avascular, no realza con contraste y es posible observar áreas de mayor hiposeñal por el tejido de granulación así como áreas de hiperseñal por su elevado contenido en proteínas y sangrados de repetición. El mucocele es infrecuente a este nivel y su imagen en la RMN es variable, si es reciente suele ser hipodenso en T1 por su bajo contenido en proteínas y si es crónico es brillante en T1 y T2. Además su pared mucosa realza con el contraste. Otra entidad seria el colesteatoma primario o quiste episidermoide de la punta del peñasco, que se presenta como una lesión expansiva isodensa o hipodensa en el TC, hipodensa en T1 e hiperintensa en T2 en la RMN y cuya pared presenta un refuerzo con el contraste. En cualquier caso el diagnóstico definitivo es el estudio anatomopatológico. ${ }^{14}$

Respecto al tratamiento, una vez diagnosticada la enfermedad de base debe iniciase tratamiento sintomático, siendo de elección la carbamazepina aunque también se han probado con otros fármacos de uso habitual en las neuralgias. En el caso de síntomas progresivos o no controlables de los tumores benignos o en el caso de neoplasias malignas, el tratamiento debe ser quirúrgico, siendo en el caso del granuloma de colesterol de la punta del peñasco de elección el abordaje preauricular infratemporal. ${ }^{15,16}$

En nuestro caso, al ser un tumor benigno y presentar excelente respuesta al tratamiento sintomático con carbamazepina, se opto por actitud conservadora por el momento.

\section{Bibliografía}

1. Horowitz SH. Isolated facial numbness: clinical significance and relation to trigeminal neurophaty. Ann Intern Med 1974;80:49-53.

2. Ashworth B, Tait GBW. Trigeminal neuropathy in connective tissue disease. Neurology 1971;21:609-614.

3. Dalmau J, Grauss F. Neuropatía mentoniana. Neurología 1986;1:203-11. patients describe dysesthesia as being moderately intense, $60 \%$ report occasional neuropathic pain and $80 \%$ have hypoesthesia upon neurological exploration. ${ }^{8}$ The malignant mental neuropathy is characterized by spontaneous anesthesia of the region of the mental nerve, and the sensitive deficit that includes the chin skin and the inferior lip mucosa. Among those that have cholesterol granulomas, fatty tumors are very uncommon. They are $0.1 \%$ of all the intracranial tumors and are generally asymptomatic. They are normally found in the mediosagittal, close to the callous body and cerebella point. They are sometimes found, but not very often, in the dorsal mesencephalon, vermiform lobe, medulla and spinal cord base. ${ }^{10-12}$

It is absolutely necessary to perform a complete radiological study of the trigeminal neuralgia in order to rule out brain and trunk lesions as well as preganglionated roots or Gasser ganglion and cavernous sinus. Just like in the extra cranial zone all along the 3 branches of the $\mathrm{V}$ cranial nerve. ${ }^{12}$

Brain image techniques help us carry out the differential diagnostic of the distinct lesions that affect the petrous bone point. The cholesterol granuloma is shown in an expansive process, hyper intense in the CAT where there is also adjacent bone erosion and the hyper intense MRI with a potency of T1, T2, Flair and proton density, cancelling its signal in fat suppressing sequences. ${ }^{12,13}$ The central cavity is a-vascular, doesn't enhance the contrast and we are able to see areas with high hypo signal through the granulated tissue. For example areas of hyper signal, because of its high protein content and repetitive bleeding. The muccocell is uncommon and its MRI is variable. If it is recent it is usually hypo dense in the T1 because of its low protein content and if it's chronic it is shiny in T1 and T2. Its mucosa wall is enhanced by the contrast. Another entity is the first cholesteatoma or episidermoide of the point petrous bone that looks like an expansive lesion that is isodense or hypo dense in the CT, hypo dense in the T1 and hyper intense in T2 of the MRI and whose wall is reinforced with contrast. In any case the definitive diagnostic is the anantomicopathological study. ${ }^{14}$

Regarding treatment, once the illness has been diagnosed symptomatic treatment should be started. Carbamazepine is the treatment of choice although other pharmaceuticals have been used in neuralgias. In the case of progressive or uncontrollable symptoms of benign tumors or in the case of malignant neoplasias the treatment should be surgical. The treatment approach chosen for a cholesterol granuloma at the petrous bone point was preauricular infra temporal. ${ }^{15,16}$

In our case, because it is a benign tumor it presents an excellent response to carbamazepine symptomatic treatment, we choose a conservative attitude at the moment. 
4. Cousin GC, llankovan V. Mental nerve anaesthesia as a result of mandibular metastases prostatic adenocarcinoma. Br Dent J 1994;177:382-4.

5. Bullit E, Tew JM, Boyd J. Intracraneal tumors in patients with facial pain. J Neurosurg 1986;64:865-71.

6. Peñarrocha $M$, Peñarrocha MA, Soler F. Neuralgia trigeminal típica secundaria a tumores del ángulo pontocerebeloso. A propósito de dos casos. Medicina Oral 1997;2:109-12.

7. Peñarocha- Diago M, Mora- Escribano E, Bagan JV, Peñarocha Diago M. Neoplastic Trigeminal neuropathy: presentation of 7 cases. Med Oral Patol Oral Cir Bucal 2006;11:106-11.

8. Hagen N, Clarke - Stvens J. Trigeminal sensory neuropathy associated with connective tisuue disease. Neurology 1990;40:891-6.

9. Teasdall Rd, Frayha RA, Shulman LE. Cranial nerve involvement in systemic sclerosis (scleroderma): A report of 10 cases. Medicine (Baltimore) 1980;59:149-59.

10. Smirniotopoulos JG, Lee SH. Tumores primarios del sistema nervioso central en el adulto. En Lee SH, Rao KCVG, Zimmerman RA. RM y TC craneal. Ed Marbán 1994.
11. Cohen ME. Primary and secundary tumors of the cebtral nervous system. In: Bradley WG, Daroff RB, Fenichel GM, Marsden CD. Naurology in clinical practice. Butterworth- Heinemann 1995.

12. Vaquero J, García Salazar F. Tumores intracraneales de carácter disembrioplásico. En: Vaquero J. Neurología quirúrgica. Ed Eurobook 1995.

13. Guerrero Peral AL, Marcos Ramos RA, Valle Antolin FJ, Jimenez de la Fuente $D$ et al. Neuropatía asilada del nervio trigémino asociada a tumor graso en el cavum de Meckel. Rev Neurol 1999;28:1065-7.

14. Mafee MF, Kumar A, heffner DK. Epidermoid cyst (cholesteatoma) and colesterol granuloma of the temporal bone and epidermoid cyst affecting the brain. Neuroimaging Clinics of $n$ Am 1994;4:561-78.

15. Oyama K, Ikezono T, Tahara S, Shindo S, Kitamura T, Teramoto A. Petrous apex cholesterol granuloma treated via the endoscopic transsphenoidal approach. Acta Neurochir 2007;149:299-302

16. Zini C, Gandolfi A, Piazza F, Avendano A, Perez R, Vega F. Granuloma colesterinico de la punta del peñasco. Acta Otorrinolaringol Esp 1997;48:496-500. 